\title{
Branding post-communist Romania and its effects on country image
}

\author{
Anca-Georgiana ANDREI \\ The Bucharest University of Economic Studies, Bucharest, Romania \\ E-mail: anca.georgiana.andrei@gmail.com
}

\begin{abstract}
In recent years, more precisely from 1989 on, which was considered by a lot of experts the beginning of the second stage of globalization, nation branding campaigns have started to be launched in more and more countries in order to help developing nations image and reputation and to provide a competitive edge on economic, social and even political areas. Simon Anholt and Wally Olins are the two authors who studied the most nation branding phenomenon and came up with theories which were applied often by professionals when elaborating nation branding campaigns for different states. Nadia Kaneva, Keith Dinnie, Melissa Aronczyk, Luminita Nicolescu and Alina Dolea have also focused their researches on this theme and manage to contribute with new and interesting ideas to the field. This paper provides insight into the most important nation branding campaigns made by Romania starting from 1989 until present. Through a comparative analysis of those campaigns the paper tries to identify which was their impact on Romania's image or reputation. How was Romania perceived (from the image perspective) before 1989 at international level? Did the image change after 1989? And what was the impact of the most important branding nation campaigns implemented after 1989 in the image of Romania and implicit in economy? These are the main questions this paper tries to answer. At the same time, the study also explores briefly the concept of globalization, nation branding, national image and national reputation. The conclusions of the paper will provide in the end a general background of all studied nation branding campaigns which will include the similarities and differences between them, but also both strong and weak points. Its aim is to contribute, among other existing papers, as a starting point for researchers or professionals who want to elaborate nation branding strategies for Romania or other countries.
\end{abstract}

Keywords: nation branding, country image, nation branding campaign, globalization, comparative analysis, SWOT.

\section{Introduction}

Romania was a communist country, from 1948 until 1989, ruled by the dictator Nicolae Ceausescu, starting 1967. Because of the antidemocratic totalitarian regime from that period, Ceausescu and communism became two of the main key terms which were identifying Romania on the map of the world from the point of view of country image (Dolea, 2015).

Djuvara said that 50 years of communism broke Romanians' soul and that first thing that can be done for branding this nation is to write the correct history (Sorin, 2015). After the 1989 Revolution, Romania emerged from communist domination and became a democratic country. Simultaneously, more similar events had taken place: fall of Berlin Wall, fall of communism in all Eastern Europe (1989) followed shortly by Soviet Union division and USA supremacy display (1991).

Events taken at this level made economic experts to draw the conclusion that starting 1989, it began a new stage of globalization (Lupan, 2009). Under those circumstances, the competition between countries raised. In order to succeed, countries needed to explore niches and to gain competitive advantage. 
In this context, country marketing started to develop more and more and made countries to preoccupy by their image and reputation because a country's brand can profoundly shape its economic, cultural and political destiny, as well as international competitiveness (Nicolescu, 2012).

The importance of a place and of its culture is strengthened by globalization (Lovell, 1998). In present times, the place becomes even more important than before (Amin et al., 1994; Meyer, Gerschiere, 1999; Robertson, 2001).

All the arguments mentioned above made Romanian's governments to invest in nation branding campaigns in order to improve country image.

This paper analyzes four of the most important nation branding campaigns in postcommunist Romania and tries to show their impact in country image. Every campaign will be analyzed based on certain criteria mentioned below, in order to identify if they accomplished their purpose or not. The article also proposes to provide a general background which can be taken in consideration by researchers and professionals when elaborating strategies for nation branding campaigns, particularizing on Romania. The background is based on a SWOT matrix, where are mentioned strengths and weaknesses from all the four campaigns, but also opportunities and threats which present key points which should be taken in consideration for future campaigns.

\section{Literature review}

The research in country marketing domain has been first focused on discussions about country image or reputation. Howard et al. (1968) are the first who tried to explain this notion. Nation Branding concept was coined first by Simon Anholt in 1996, who has also become most prolific author on this topic (Dinnie, 2008). Anholt (2007, 2009, 2010) described in his papers the entire process of nation branding, coming at the same time with innovative theories about how to measure nation branding.

Marketing experts are often highlighting the difference between country image/reputation and nation brand, an aspect also very important for understanding the subject of this paper. "The difference between country image/reputation and nation brand is that the image or reputation of a country can be created without any concrete actions, while nation brand is the image of a country as a result of the efforts made by the nation in this purpose. So, nation brand is more than country image, it is a country image influenced consciously and directed in a favorable direction for the country (Nicolescu, 2008, p.32).

Another relevant author for this domain is Wally Olins $(1999,2003,2008)$ who has also analyzed Romania's country image and was ready to build a new nation brand for 1 million dollars a year (Gandul, 2007).

Olins remarked, when making this offer to the Romanian authorities that "perceptions are much worse than reality; reality is better and improves every day, but perceptions are bad and they don't improve at all"(Gandul, 2007).

Nicolescu $(2007,2008,2012)$ also concluded that "as far as Romania is concerned, there is the need for creating and repositioning of its image abroad".

Dolea $(2009,2015)$ analyzed Romania's nation branding campaigns and came to the conclusion that the way those were conceived showed a lack of research in this field particularizing on Romania. 
Aronczyk (2013), Dinnie (2008) and Kaneva $(2011,2012)$ focused their researches more on determined nation branding campaigns from different countries, practically they based a lot their work on case studies.

Kaneva $(2011,2012)$ chose Romania as subject for her papers and stated that "the authors argue that the government's efforts are predestined for failure as they do not engage the wide support of the Romanian population and, in the end, are aimed at producing narratives that satisfy the desires of a Western gaze more than anything else."

\section{Research methodology}

Taking in consideration the researcher's conclusions mentioned above, the objective of this paper is to provide a general background of the current situation of Romania's image and to draw some conclusions which could be used by experts in nation branding when elaborating new strategies for Romania's branding campaigns.

In order to attain this objective, I compared four of the most important nation branding campaigns, analyzing the next aspects:

$>$ Agent - who launched the campaign;

$>$ Purpose of the campaign;

$>$ Cost of the campaign;

$>$ Website of the campaign;

$>$ Number of foreign tourists attracted one year after the nation branding campaign based on information provided by National Institute of Statistics (2017);

$>$ Relevant evaluation provided by the initiating institution which provides data regarding the consequences of the campaign.

Monitoring the international media can be an effective way of understanding the image of a country (Anholt 2007, 2009), that's why I have also used in my paper data withdrawn from media analysis.

Based on these aspects, a SWOT analysis will show the conclusions of this paper.

Before withdrawing relevant data based on numbers, it is first necessary to make a summary of the four branding campaigns, starting with the description of the events which determined Romanian authorities to invest in branding.

This short presentation is necessary in order to better understand how certain actions can have a very big impact on country image, whether there are parts of a campaign of institutions, whether there are spontaneous actions.

\section{Short review of Romania branding campaigns after 1989 Eternal and Fascinating Romania - 1994}

Agent. In 1994, the idea of branding Romania had become one of the main preoccupation of the authorities. So in 1996, Romanian Government with the support of the Romanian Presidency launched the campaign Eternal and Fascination Romania.

Description. The branding campaign consisted in a 513 photos album with texts translated in French, English, Arab, Spanish, Japanese, Italian and Romanian. The album should have been printed in 97000 copies which should have been sent in 96 countries. Until the end of contract, march 1998, only 10.000 copies from which 4200 were sent in Romania. First 1.333 were considered special edition, and there were sent as protocol to different Romanian personalities (Surcel, 2006). 
Its purpose was to change/improve Romania's image abroad.

The cost was of 5,97 million dollar (5,61 million euro) and it was paid by the sponsor Bancorex, a former Romanian Bank, which was liquidated in 1999 and absorbed later by Romanian Commercial Bank (BCR).

It had no website and no continuation.

There was no evaluation of this branding campaign of the Romanian authorities, but shortly after the end of it a corruption scandal covered the front page of all papers.

Before the campaign, in 1994, Romania received 856.136 foreign tourists and after the end of the campaign, in 1999 the number decreased to 832.775 (INSSE, 2017).

\section{Romania, Simply Surprising - 2001}

Agent. In 2001, the Directorate General for Tourism Promotion launched a call for a new nation branding campaign.

Its purpose was to attract foreign tourist. The cost was considerable, 20 million dollars (18.692.000 euro)

Description. In 2004, it was launched the nation branding campaign which was actually an advertising campaign focused on commercial spots on international television (Euronews, Eurosport, Discovery, CNN, BBC) and banners in print newspapers. Although it had a correct media planning, it was broadcasted on the international televisions during holiday period. In the end, the campaign was abandoned without the publication of an evaluation (Nicolescu, 2008).

The campaign was later criticized by the World Tourism Organization for not communicating the essence of Romania. (Sepi, 2013).

The campaign had no website and no evaluation was shown public by authorities.

Regarding the number of foreign tourists, the number increased. In 2000, before launching the idea of the new campaign, the numer of foreign tourist was 867.024 and in 2005, one year after the campaign almost doubled, 1.429.911 (INSSE, 2017).

\section{Romania, Land of Choice}

Agent. In 2009, Ministry of Tourism headed by Minister Elena Udrea launched the campaign Romania, Land of choice. It was part of the project "Creating a positive image of Romania as a tourist destination by defining and promoting the national tourism brand" (Stan, 2013), project funded with 75 million euro allocated through the Regional Operational Program, Axis 5, 2007-2013.

The purpose of this campaign was to increase the number of foreign tourists coming to Romania of at least $10 \%$ the year following the campaign (Rhn, 2009).

It is very difficult to estimate what was the exact cost of this campaign, but certainly a few million euro.

Description. The campaign consisted in broadcasting commercial videos on the media facade of Cocor Media Channel (former store Cocor from Bucharest) for a week, but also on tv channels, Eurosport and CNN.

The endorsers of this campaign were the most important athletes Romania ever had: Nadia Comaneci, Gheorghe Hagi and Ilie Nastase. The tv spots were broadcasted for five months, 550 time on Eurosport, 475 times on Eurosport and 529 times on CNN. For Eurosport, the minister paid 1,2 million euro and 400.000 euro for CNN. 
The fees for the three stars and the spot production was paid by BRD, Group Societe Generale which already had a contract with them (Pascu, 2009).

The campaign might have had a website, but today, everything that remained from this campaign is this portal (http://www.landofchoice.ro) which is active, but it represents a collection of funny pictures that are not necessarily from Romania. It is not known who the owner of it is. What is known is that Romania, land of choice was registered at OSIM (State Office for Inventions and Trademarks) by a person who had nothing to do with this campaign, which means that if he wants he can demand compensation, because his slogan was used in commercials without his permission.

Minister of Tourism, Elena Udrea did not publish any evaluation of the campaign, but she said that brand Romania will be launched later, after an international auction where prestigious PR agencies will apply in order to promote Romania.

The year following the campaign, the number of foreign tourists did not increase at all, but decreased. In 2008 there were 1.465.891 foreign tourists and in 20101.346 .343 who spent 3.723.400.432 lei(INSSE, 2017).

\section{Explore the Carpathian Garden}

Agent. In 2010, during the World Expo from Shanghai, the Ministry of Tourism and Development, under the leadership of Elena Udrea, together with Romanian sports legends Nadia Comaneci, Ilie Nastase and Gheorghe Hagi launched the most controversial and expensive branding campaign Romania ever had - Explore the Carpathian Garden.

The purpose of this campaign was to improve Romania's image abroad and to double the numbers of tourists by 2013.

The cost was than 56 de milioane de euro and the money were spent between 20102012. Before the campaign, a study it was undertaken to discover what Romanian consider the most. More than 2.5 million euro were spent for promoting the logo of the nation branding campaign during Lucian Bute's box matches. Other 5 million euros were allocated in advertising on 3 TV international channels, CNN, Euronews and Eurosport (Stan, 2013).

Description. Branding campaign Explore the Carpathian Garden has consisted in Romania's participation in various fairs in the world, the realization of advertising inserts in catalogs sights of major tour German operators German, and 200000 euro advertising on TV channels, TVR and Realitatea Tv (Expres Magazin, 2010).

The campaign had a website, which is still active (http://www.romania.travel/ro/) and gives relevant information about the country, but if you wanted to look for details about this, in march last year, Explore the Carpathian garden was a gardener's website which had nothing to do in Romania (http://www.carpathiangarden.com). The website in now for sale for 3195 dollars.

Like all the other initiators of branding Romania, The Minister of Tourism did not publish a relevant evaluation in order to measure the impact of the campaign.

The number of foreign tourists did not doubled, but it increased from 1.346 .343 foreign tourists in 2010 to 1,5 million in 2012 to 1.71 million in 2013 who spent 4,79 billion RON (INSSE, 2017). 


\section{Results and discussions Building Romania's brand}

Based on the four campaigns analysis there are a number of strengths and weaknesses, regarding the way Romania's branding campaigns were built, presented in Table 2 . Also a number of opportunities and threats withdrawn from a short analyze of the international context completes Table 2 .

Table 2. SWOT analysis for Romania's branding campaign building

\begin{tabular}{|c|c|}
\hline Strengths & Weaknesses \\
\hline $\begin{array}{l}\text { - Important Romanian public } \\
\text { institutions realized the importance } \\
\text { of nation branding and invested in } \\
\text { image campaigns; } \\
\text { - Special budget allocated for nation } \\
\text { branding campaigns; } \\
\text { - Increasing number of foreign tourists } \\
\text { starting 1996; } \\
\text { - Positive messages of Romania in the } \\
\text { international media/tv through } \\
\text { advertising; }\end{array}$ & $\begin{array}{l}\text { - Lack of relevant studies which should } \\
\text { involve all actors when building the } \\
\text { campaign } \\
\text { - Lack of evaluation after Romania's } \\
\text { branding campaigns in order to identify } \\
\text { strengths and weaknesses } \\
\text { Lack of transparency when choosing } \\
\text { private companies to work on Romania's } \\
\text { branding campaign /risk of corruption } \\
\text { accusation; } \\
\text { 4 out } 5 \text { campaigns abandoned; } \\
\text { - Lack of online promotion; } \\
\text { - Lack of interesting PR stories which } \\
\text { should attract media's attention; } \\
\text { Total lack of coordination between the } \\
\text { institutions and other actors involved in } \\
\text { the process; } \\
\text { Absence of connection between the } \\
\text { nation branding campaign and the } \\
\text { citizens. }\end{array}$ \\
\hline Opportunities & reats \\
\hline $\begin{array}{ll}\text { - } & \text { Romania EU member; } \\
\text { - } & \text { Romania NATO member; } \\
\text { - } & \text { Romania safe country in the context } \\
& \text { of terrorist attacks; } \\
\text { - } & \text { Romania IT business hub; } \\
\text { - } & \text { Romania, safe holydays, beautiful } \\
\text { country. }\end{array}$ & $\begin{array}{l}\text { - Intensification of globalization which } \\
\text { favors developed countries with advanced } \\
\text { economies; } \\
\text { Too many international articles based on } \\
\text { Romanian corruption - risk of country } \\
\text { image as corrupt country; } \\
\text { - Politic and economic instability which } \\
\text { creates an unpredictable environment. }\end{array}$ \\
\hline
\end{tabular}

Authors' own research.

Table 2 shows that nation branding campaigns are necessary and can constitute added value for country image. But at the same time, analyzing four of them in comparison, it can be concluded that there is a lack of coordination between the actors which should have been involved in the process and that there are missing important steps necessary for a successful nation branding campaign.

\section{Conclusion}

The campaigns analyzed above have many similarities and are based on same principles. All four were initiated by public institutions, three by Minister of Tourism (Romania, Simply Surprising; Romania, Land of Choice; Explore the Carpathian Garden ) and one by Government (Eternal and Fascinating Romania). All four had the main purpose of improving Romania's image and then to increase the number of tourists. 
None of the campaigns had any evaluation after its final and only "Explore the Carpathian Garden" undertook a study before building the campaign in order to find out on what values should base the concept, the "truth" explained by Olins above.

Citizens' perception about their own country is reflected in the country's image both internally and externally. Anholt noted that countries where people have a good image about their country can develop a very strong country brand. It argues that if a country's citizens do not believe in the power of their country, then they will not be able to persuade others to believe (Gandul, 2007). To build a strong country brand, first it must be crept in the minds of citizens, otherwise any attempt at branding the country will result in failure.

This important connection between the people and the campaign missed almost completely from all the attempts of branding Romania, which can be observed from the descriptions of the campaigns. One of the most serious problems was the fact that citizens were not involved at all in the campaigns. So, Romania's brand should have been created by the specialists together with the people and promoted involving the people.

Anholt(2007) considers that nation branding management should be a part of national policy and not a separate campaign of government program or a separate campaign of economic growth plan. In Romania, all four attempts of branding were rather independent campaigns without coordination and connection between the actors which should be part of the process.

So, in conclusion, in order to build a successful nation branding campaign, first it should be found the concept, the truth Olins(2007) was mentioning, involving all the citizens and all the other actors (Government, industry, media, people, opinion formers, specialists in branding). Then, the concept must be integrated in country program elaborated by the Government. This one should be assumed and continued even if Government changes, because a permanent reform stops solid construction.

Identifying an existent natural identity (Nicolescu, Paun, Popescu, 2008) could be useful for country branding and sometimes identifying facts in a regional identity in our case European identity can be very relevant (Diaconescu, Nicolescu, Panzaru, 2007).

The four campaigns analyzed above show this lack of connection and solid construction necessary for a successful branding process. Each one of them revealed a new beginning every time and in the end none managed to accomplish the assumed objective. And at the same time none was able to transmit a strong and durable message abroad to improve Romania's image.

As a final conclusion of this paper, it can be said that Romanian institutions should start the branding campaign first inside the country and then promoted outside, because if the Romanian citizens do not believe in Romania's brand, then foreigners will not believe either.

\section{References}

Amin, A.,Thrift, N. (1994), Living in the Global. Oxford, Oxford University Press. Anholt, S., (2007). Competitive Identity, New York, NY: Palgrave Macmillan.

Anholt, S., (2009). The media and national image. Place Branding and Public Diplomacy, New York, NY: Palgrave Macmillan.

Anholt, S. (2010). Places: Identity, image, and reputation. New York, NY: Palgrave Macmillan. 
Aronczyk, M. (2013). Branding the Nation - The Global Business of National Identity, New York, NY: Oxford University Press.

Capital (2004). Romania, "mereu surprinzatoare" cand isi liciteaza imaginea. Retrieved from http://www.capital.ro/romania-mereu-surprinzatoare-cand-isi-liciteazaimaginea-16023.html.

Diaconescu, M., Nicolescu, L.,Panzaru, F.(2007). Romania within the EU: opportunities, requirements and perspectives, Sibiu, Conference Proceedings volume 1, 2007, pp. 135-141.

Dinnie, K., 2008. Nation branding: Concepts, issues, practice. Oxford, UK: Elsevier.

Dolea, A., Tarus, A. (2009). Branding Romania. Cum (ne)promovam imaginea de tara. Bucuresti, Curtea Veche.

Dolea, A., (2015). Twenty years of (re)brandingpost-communist Romania, Iasi, Institutul European.

Expres Magazin, (2010). Frunza din brandul de țară poate fi cumpărată de pe internet cu 250 de euro. „Grădina” Elenei Udrea costă însă 75 de milioane de euro. De la Shanghai, Udrea se ceartă cu ziariştii. Retrieved from http://www.expresmagazin.ro/frunza-din-brandul-de-ar-poate-fi-cumprat-de-peinternet-cu-250-de-euro-aezgrdinaae\%C2\%9D-elenei-udrea-cost-ns-75-demilioane-de-euro-de-la-shanghai/.

Gandul, (2007). Wally Olins ar accepta sa construiasca "brandul de tara" pentru Romania .

Retrieved from http://www.gandul.info/magazin/wally-olins-ar-accepta-saconstruiasca-quot-brandul-de-tara-quot-pentru-romania-280392.

Howard, J., Sheth, J.N. (1968), Theory of Buyer Behavior, New York, NY: J. Wiley \& Sons, Institutul National de Statistica, INSSE (2017). Retrieved from http://www.insse.ro/. Lovell, N. (1998). Introduction: belonging in need of emplacement?, London, Routledge.

Kaneva, N. (2012). Branding Post-Communists Nations. New York, NY: Routledge.

Kaneva, N., Popescu, D. (2011). National Identity Lite: Nation Branding in Post communist Romania and Bulgaria. INTERNATIONAL journal of CULTURAL studies, Volume 14(2), pp.191-pp. 207.

Lupan, M. (2009). Globalizarea Economiei. Retrieved from Marin, M. (2007, March 1). http://www.seap.usv.ro/ ro/cursuri/ECTS/ECTS_GE.pdf.

Meyer, B., Gerschiere, P. (eds) (1999). Globalization and Identity: Dialects of flow and closure, Oxford, Blackwell.

Nicolescu, L., Cojanu, V., Popescu, A., Drăghici, A. (2007). Developing country branding: a key factor for international competitiveness, Bucharest, National School of Political Studies and Public Administration and Comunicare.ro, Editura SNSPA, pp. 285-291.

Nicolescu, N. (2008). Imaginea României sub lupă! Branding şi rebranding de ţară, Bucuresti, Editura ASE, 2008.

Nicolescu, N., Paun, C.,Popescu, A.I., Draghici, A., Pinzaru, F. (2007), National identity an essential element for country branding. The case of Romania, Review of Management and Economical Engineering, special issue, Volume 6, no.6, pp. 78-83.

Nicolescu, N., Paun, C., Popescu, A., Draghici, A. (2008). Romania trying to be an European brand, Revista de Management şi Marketing, Vol. 3, no. 1 (9), pp. 61-72. 
Olins, W. (1999) Trading Identities: Why countries and companies are taking each other others' roles, London, The Foreign Policy Centre.

Olins, W. (2003). On Brand. London, Thames and Hudson.

Olins, W. (2008), The Brand Handbook, London, Thames and Hudson.

Pascu, R. (2009, August 6). "The Land of Choice" pe ecrane, Retrieved from http://razvanpascu.ro/2009/08/06/the-land-of-choice-pe-ecran/.

PICBE | 512

Robertson, R. (2001), Globalization theory 2000+: Major Problematics. In: Ritzer, G. and Smart, London, Handbook of Social Theory.

Romania Insider, (2010). Romania launches "Explore the Carpathian garden" slogan, public doubts logo uniqueness. (2010, July 29). Retrieved from http://www.romania-insider.com/romanialaunches-tourism-campaign-under-explore-the-carpathian-garden-slogan/.

Surcel, V. (2006, December). Bibliofilie scumpa - o carte cat un munte de bani. Retrieved from jurnalul.ro/special-jurnalul/bibliofilie-scumpa-o-carte-cat-un-munte-debani-6628.html.

Sepi, A. (2013, October). Nation Branding: The Case of Romania. Retrieved from http://www.culturaldiplomacy.org/pdf/case-studies/Andreea_Sepi__Nation_Branding_-_The_Case_of_Romania.pdf

Sorin, C. (2015, September 10). Neagu Djuvara: 99 de ganduri si obsesii. Retrieved from http://www.qmagazine.ro/neagu-djuvara-99-de-ganduri-\%C5\%9Fiobsesii_271177.html.

Stan, E. (2013, February 27). Elena Udrea a produs cea mai scumpă frunză din lume. Realizarea şi promovarea brandului turistic au costat peste 20 de milioane de euro. Retrieved from http://jurnalul.ro/special-jurnalul/anchete/ceamai-scumpa-frunza-din-lume-realizarea-si-promovarea-branduluituristic-au-costat- peste-20-de-milioane-de-euro-637896.html.

9am. (2007). Fabulospirit - 5.000.000 de euro. Retrieved from http://www.9am.ro/stirirevista-presei/Actualitate/56321/Fabulospirit-5-000-000-de-euro.html\#ixzz3 yWQEZolL.

Eterna şi fascinanta Românie”. SGG trebuie să despăgubească BCR cu 5,8 milioane de dolari. (2016, June 27). Retrieved from http://www.bibme.org/citationguide/apa/website/.

EUR 88,000 for launching Romania's promotion campaign abroad. (2009, June 6). Retrieved from http://www.rhn.ro/en/eur-88-000-for-launching-romania-spromotion-campaign-abroad-26189.

Fabulospirit. (2008, March 30). Retrieved from https://rebrandingromania.wordpress.com /2008/03/30/fabulospirit/. 